\title{
BALANCED SCORECARD: AN EFFECTIVE MEASUREMENT APPROACH FOR HIGHER EDUCATION INSTITIUTES IN THE $21^{\text {st }}$ CENTURY \\ Ahmed M. El Essawi
}

\begin{abstract}
Studies showed that no organization can improve its performance unless it assesses its status quo. And, assessing the status quo needs an effective balanced tool. That was the base on which Robert Kaplan and David Norton developed the Balanced Scorecard (BSC) which has shown high effectiveness and success in assessing the performance of business organizations since 1992. Lately, a notion of adapting the Balanced Scorecard in the education sector has emerged. In the $21^{\text {st }}$ century, there is an inclusive view to the educational institutes. This view includes different perspectives such as leadership, strategic planning, students and other stakeholders, teaching and learning, faculty and staff, and organizational performance. For this reason, there should be a successful system, like the Balanced Scorecard, to evaluate these perspectives in order to set improvement plans for the higher education institutes to help them cope with the $21^{\text {st }}$ century requirements and skills. However, very few studies worldwide has been conducted to investigate the impact of applying the Balanced Scorecard in higher education institutes. Thus, the Educational Foundations Department in the Faculty of Education, Mansoura University has taken this initiative to conduct this study to examine the impact of applying the Balanced Scorecard, as a successful evaluation framework, on the performance of higher education organizations. The case study of the Faculty of Education, Mansoura University will provide the researcher of a rich source of data to test hypothesis. The findings from this case study can be generalized in other Egyptian higher
\end{abstract}

education institutes which are in a very bad need to improve their performance in preparing citizens who are able to meet the challenges of the $21^{\text {st }}$ century.

Key Words: Balanced Scorecard: is a strategic planning and management system which takes into account non-financial aspects of corporate performance, such as customer satisfaction and business processes, to create a complete picture of how the company is likely to perform in the future.

Measurement: the action of measuring something

Faculty of Education: an institution where schoolteachers are trained

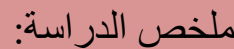

لقد أظهرت الدراسات أن أي مؤسسة لا لانة

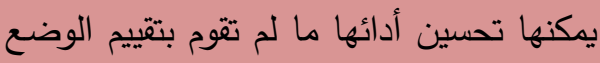

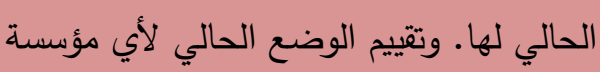

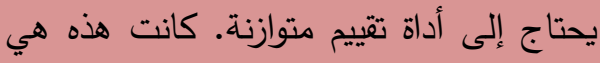

القاعدة التي اعتمدا عليها روبرت كابلن و

ديفد نورتون عند استحداثهما بطاقة قياس

الأداء المتوازنة التي أظهرت نجاحاً وفاعلية

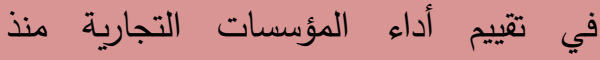
ب99 19 ـ وحديثا ظهرت فكرة تطبيق هذه الأداة

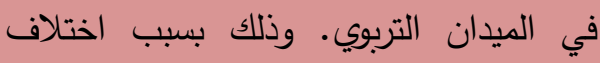

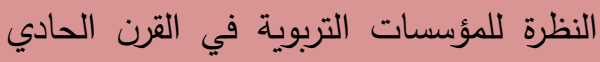

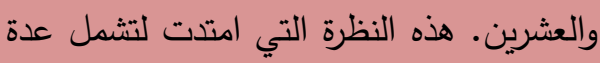

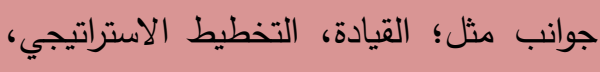

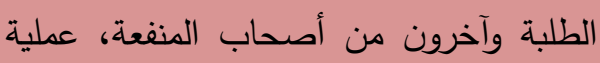




$$
\begin{aligned}
& \text { التعليم والتعلم، أعضاء هيئة التدريس } \\
& \text { والموظفين، والأداء المؤسسي. ولهذا السبب، } \\
& \text { كان لابد من استخدام أداة ناجحة متوازنة ولنة ولنداء } \\
& \text { كمثل بطاقة قياس الأداء المتوازنة، لتقييم هذه دانه }
\end{aligned}
$$

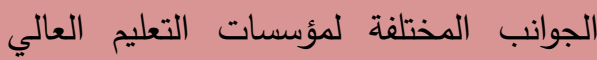

$$
\begin{aligned}
& \text { لوضع خطط تحسين تمكنها من مواجهة } \\
& \text { متطلبات ومهارات القرن الحادي والعشرين. } \\
& \text { لكن الدراسات التي أجريت على مستوى العالم } \\
& \text { للتحقق من إمكانية تطبيق بطاقة قياس الأداء } \\
& \text { المتوازنة في مؤسسات التعليم العالي قليلة } \\
& \text { جداً. ولذلك، قام باحث في قسم أصول التربية } \\
& \text { في كلية التربية بجامعة المنصورة بهذه الدراسة } \\
& \text { للتحقق من أثر تطبيق بطاقة الأداء المتوازنة، } \\
& \text { كأداة تقييم ناجحة، على أداء مؤسسات التعليم تلطي } \\
& \text { العالي. وستوفر دراسة الحالة هذه التي تتناول } \\
& \text { كلية التربية بجامعة المنصورة البيانات اللازمة } \\
& \text { للباحث للتحقق من افتراضات الدراسة لتعميم } \\
& \text { النتائج على مؤسسات التعليم العالي المصرية }
\end{aligned}
$$

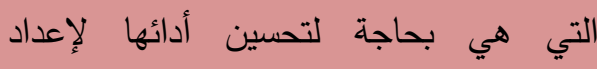

$$
\begin{aligned}
& \text { مواطنين قادرين على مواجهة تحديات القرن }
\end{aligned}
$$

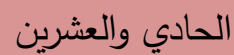

\section{Introduction}

In an increasingly complex, demanding and competitive world, higher education institutes need to rethink their programs, plans and strategies to redirect them to well prepare $21^{\text {st }}$ graduates who are able to meet the challenges of the age. Education is no more the process to prepare good, perfect and well-trained citizens. Today, education means creativity: the capacity to learn and a lifelong willingness to face new things and modify learned expectations accordingly; there can be no learning without relearning. Conventionally, education has been understood as preparation for life, as personal realization, and as an essential element in progress and social change, in accordance with changing needs (Chitty, 2002). Orr (2004) declares that if certain precautions are not taken, education may equip people to become "more effective vandals of the earth". He describes education of the sort we have seen thus far as a possible problem, and argues for a new type of education:

"More of the same kind of education will only compound our problems. This is not an argument for ignorance but rather a statement that the worth of education must now be measured against the standards of decency and human survival. It is not education, but education of a certain kind, that will save us."(Orr, 2004: 8)

According to the World Declaration on Higher Education for the 21st Century (1998), higher education is facing a number of important challenges at the international, national and institutional levels.

At the international level, there are two main challenges. The first is the role of supranational organizations such as UNESCO in advancing the prospection of trends and improvements, as well as in promoting networking and twinning programs among institutions. The European Union (EC-JRC, 2010), for example, has stressed that higher education must change and adapt to economic and social needs, that institutional change is essential to educational innovation, and that information and communication technologies must form part of the teaching and learning process. The second international challenge is to encourage 
international cooperation between institutions in order to share knowledge across borders and facilitate collaboration, which, furthermore, represents an essential element for the construction of a planetary (Morin, 2009). States must provide the necessary financing so that universities can carry out their public-service function. States may also enact laws to ensure equality of access and strengthen the role of women in higher education and in society. For this reason, Education for Sustainable Development (ESD) has emerged as a paradigm for revising and reorienting today's education. Part of this necessity revising and rethinking higher education, is to assess the status quo of its organizations. And, when thinking about a tool to conduct this assessment, we will find that the Balanced Scorecard (BSC) is the most effective instrument for this process as it shows effectiveness in evaluating the performance of other organizations as an inclusive measurement tool.

\section{Problem Statement}

In February 2000, the Egyptian Ministry of Higher Education launched a big project to reform the higher education sector. A strategic plan was set to achieve the ministry targets. Neither the ministry strategic plan nor its vision (as it is published on the ministry's website) refer to a measurement tool to realize the status quo of the higher education organizations. Thus, it is obvious that there is a need to rethink the plans and strategies used for improving the performance of the Egyptian higher education institutes. Consequently, this arouses my interest as a researcher to investigate this issue.

My investigation will help the decision makers take the proper decisions to enhance the performance of the higher education organizations. The rationale for choosing this topic lies within my belief that higher education organizations have a big role to bridge the gap between their products and the labor market of $21^{\text {st }}$ century by preparing graduates who are equipped with $21^{\text {st }}$ century skillscreativity, collaboration, communication, and critical thinking.

\section{Research Question}

The lack of the proper assessment tool to measure the performance of the higher education organizations arouses my interest to answer two basic questions:

1. What impact does the application of the Balanced Scorecard, as an organizational assessment tool, have on decision making to improve the performance of the Egyptian higher education organization?

2. To what extent do decision makers consider the assessment of the status quo of the higher education institutes when they set improvement plans?

3. To what extent does the application of the Balanced Scorecard, as an organizational assessment tool, help the Faculty of Education, Mansoura University set plans and programs that enable its graduates meet the challenges of the $21^{\text {st }}$ century?

\section{The study objectives:}

The study aimed to:

1. Assessing the status quo of the faculty of education, Mansoura University, in terms of the organizational performance.

2. Identify the role of using the Balanced Scorecard to measure the performance of the higher education institutes.

3. Providing the decision takers with data needed for strategic planning.

\section{Significance of the study}

There has been a lot of researches on the performance of the higher education organizations worldwide. However, there has been little research about the implementation of Balanced Scorecard (BSC) in assessing the performance of the higher education organizations worldwide and in the Arab world in particular. Thus, I believe that my research will contribute to 
the enrichment of the literature in the field of higher education.

Using the Balanced Scorecard (BSC) as the proper assessment system, can help higher education organizations set the right objectives, strategies, plans and actions to develop their performance and give them a real image of where they are and where they want to go because the Balanced Scorecard has many advantages. The first advantage of using the Balanced Scorecard method is that by looking at key performance indicators (KPIs) of any higher education organization, you really do get a balanced image of its performance. Unlike traditional methods of tracking the academic performance, the balanced scorecard gives you a full picture as to whether the educational institution is meeting its objectives or not.

Second, when the Balanced Scorecard approach is used, the near future isn't the only thing being assessed. Many aspects, such as students' enrollment, grade point average, scores on standardized tests, retention rates, graduation rates, are all investigated in a parallel method. Third, using balanced scorecards let stakeholders determine the short, medium, and long term objectives at a glance. Finally, using the Balanced Scorecard enables a higher education organization align the strategic action implemented with the desired outcomes. All in all, I think this study will improve the performance of the higher education organizations.

This detailed view of the Balanced Scorecard application will be helpful for higher education administrators who are both internal and external to Faculty of Education Mansura University. For current FoEMU administrators, this study will provide them with a new view of the Balanced Scorecard. For external higher education administrators, this study will provide them with an effective model to implement to assess the performance for of their organizations. They will have a detailed view with examples of how one higher education organization has applied the Balanced Scorecard and impacted its performance.

\section{2-PRELIMINARY LITERATURE REVIEW}

There has been a lot of research done to investigate the role of the Balanced Scorecard (BSC) as an effective framework to assess performance of organizations. A lot of the research has been conducted on the profit organizations. In fact, a few studies have pointed out that the Balanced Scorecard (BSC) is a strong framework to be used by higher education organizations to know where they are and where they want to go. However, the majority of research strongly stresses the positive function of the Balanced Scorecard (BSC) in enhancing the performance of the organizations.

Kaplan and Norton (1997) stated that the Balanced Scorecard is a strategic management tool to identify the major strategically relevant issues of a business and to describe and illustrate the causal contribution of those issues that contribute to a successful achievement of an organization strategy.

The Balanced Scorecard, first proposed in the January-February 1992 issue of HBR, provides executives with a comprehensive framework that translates a company's strategic objectives into a coherent set of performance measures. Much more than a measurement exercise, the balanced scorecard is a management system that can motivate breakthrough improvements in such critical areas as product, process, customer, and market development (Kaplan \& Norton, 1993).

When asked to describe how the Balanced Scorecard helped them achieve breakthrough performance, executives of adopting organizations continually referred to two words: alignment and focus (Kaplan and Norton 2001a, Chapter 1). 
According to Rohm (2002), the Balanced Scorecard is a performance management tool that assists the organization in finding its balance. Rohm (2002) discussed this concept, stating that the Balanced Scorecard was:

Originally developed as a framework to measure private industry nonfinancial performance, Balanced Scorecard systems are equally applicable to public sector organizations, but only after changes are made to account for the government mission and mandates, not profitability, that are unique to almost all public sector entities.(p. 1).

Kaplan and Norton (1996) stated that the Balanced Scorecard provides a framework for managing the implementation of strategies while also allowing the strategy itself to evolve in response to changes in the company's competitive market, and technological environments. Kaplan and Norton explained that by aligning the management processes within an institute, this strategy can support the organization in implementing a long term strategy and vision. The Balanced Scorecard is not a means to change traditional financial measures but rather a strategy that complements the financial measures an organization is now using. Green (2003) called for a reengineering of higher education, which he described as an alternative to bureaucracy.

Gumport and Sporn (1999) said that higher education organizations need to focus on public accountability, productivity, and effectiveness; and Douglass (2010a) called for smart growth. The Balanced Scorecard is the most effective tool for the higher education organizations to address these critics. They described opportunities within higher education organizations, which allow for the injection of management strategies, the opportunities for quality expectations which focus on public accountability, student learning, faculty productivity and performance, program effectiveness, and institutional evaluation.

Halachmi (2002, 2005) has the same idea that is consistent with Kaplan and Norton (1996). According to Halachmi, an appropriate performance measurement system will be very effective as a way to improve the performance. Halachmi (2005) further explained that something that cannot be measured it will not be understood. If it cannot be understood, then it will not be controlled; and if it cannot be controlled, it will not be developed. Therefore, the organization's strategic goals and measures should be identified and linked appropriately. Thus, the performance indicators can serve as a performance management system, not merely just performance measurement. This concept is still constant with the achievement of the principles of Balanced Scorecard performance measurement system that enables organization system performance connecting to the strategy (Kaplan and Norton; 1996).

In developing a structure that links from cause to effect, Kaplan and Norton (2004) created a tool called the strategy map. The strategy map is a visual representation of an organization's strategy that describes the logic of the strategy by representing the objectives for the critical internal processes that create value and the organizational learning and growth that support those processes. These objectives are then translated by the balanced scorecard into targets and measures. The internal processes most critical to creating the customer's value propositions are referred to as strategic themes.

\section{PLANNED METHODOLOGY}

RESEARCH 
The researcher will draw data from multiple sources and triangulate by using a combination of quantitative data from questionnaires and qualitative data from interviews. First, he will construct a questionnaire to be completed by at least 100 faculty members working in the Faculty of Education, Mansoura University. The survey will also include other stakeholder (students, decision makers, representatives of local community organizations...) to assess their attitude towards the performance of the organization. The questionnaire will address relevant issues about the four perspectives of the Balanced Scorecard.

Second, the researcher also plans to conduct structured interviews with a group of other stakeholders assess their knowledge of implementing the Balanced Scorecard in higher education institutes. The researcher believe that the questionnaire and the interviews will give him a clear image about what is being done towards the higher education reform and the problems that hinder the reform. Consequently, he will build an idea and find answers to his research questions. Hence, the suggestion of developing a Balanced Scorecard for each higher education organization will be a must to fill the gap between vision and outcomes.

\section{Conclusion}

As mentioned earlier, the study was meant to address three main points: a) assessing the status quo of the faculty of education, Mansoura University, in terms of the organizational performance, b) identifying the role of using the Balanced Scorecard to measure the performance of the higher education institutes, and c) providing the decision takers with data needed for strategic planning. The results of the study revealed that the status quo in the faculty needs an effective measurement tool. In addition, the balanced scorecard is effective in evaluating the performance of the faculty of education, Mansoura University, and the data resulted from the study is reliable to plan strategically and take decisions.

\section{PRELIMINARY BIBLIOGRAPHY}

Chitty, C. (2002) Understanding Schools and Schooling, London, Rouledge Falmer

Green, R. (2003). Markets, management and "reengineering" higher education. Annals of the American Academy of Political and Social Science, 585, 196-210.

Gumport, P. J., \& Sporn, B. (1999). Institutional adaptation: Demands for management report and university administration. Stanford, CA: National Center for Postsecondary Improvement, Stanford University.

Halachmi, Arie (2002). Performance measurement, accountability, and improved performance. Public Productivity and Management Review, Vol. 25. No. 4

Halachmi, Arie (2005). Performance measurement is only one way of managing performance, International Journal of Productivity and Performance Management, Vol. 54. No. 7

http://www.guninetwork.org/resources/hearticles/the-challenges-of-highereducation-in-the-21st-century

Kaplan R, Norton D. 1997. Balanced Scorecard: Strategien erfolgreich umsetzen. Sch“"affer Poeschel: Stuttgart.

Kaplan, R. S., \& Norton, D. P. (1996, January-February). Using the Balanced Scorecards as a strategic management system. Harvard Business Review, 75-85.

KAPLAN, R. S., NORTON, D. P. (2004), Strategy Maps, Harvard Business School Publishing Corp., Boston, MA.

Morin, E. (2009), Para una Política de la Civilización, Paidós, Madrid 
Orr, D. (2004) Earth in Mind: on education, environment and the human prospect, Chicago, Island Press, 2nd Edition

Robert S Kaplan, David P. Norton (1993) "Putting the Balanced Scorecard to Work" Harvard Business Review. Boston: September-October 1993.

Robert S Kaplan, David. P. Norton. 2001. The Strategy-Focused Organization. Boston, MA: Harvard Business School Press.
Policy Dialogue 1: ESD and Development Policy, (http://unesdoc.unesco.org/images/0 017/001791/179121e.pdf)

UNESCO (2009) Trends in Global Higher Education: Tracking an Academic Revolution,

(http://unesdoc.unesco.org/images/0 $\underline{018 / 001831 / 183168 \text { e.pdf) }}$

Rohm, H. (2002). A balancing act: Developing and using Balanced Scorecard performance systems. Perform Magazine, 2(2), 1-8.

UNESCO (2008) Education and the Search for a Sustainable Future, 